\title{
Pengaruh pemberian ekstrak tinta cumi (squid ink) terhadap aterosklerosis
}

\author{
${ }^{1}$ Fajar M. Nasution \\ ${ }^{1}$ Rina S. Mardia \\ ${ }^{1}$ Ayu Azri \\ ${ }^{1}$ Rido R. Hutabarat \\ ${ }^{1}$ Fadhila Al Izza \\ ${ }^{2}$ Robitah Asfur
}

\author{
${ }^{1}$ Program Studi Pendidikan Dokter \\ ${ }^{2}$ Departemen Fisiologi Fakultas Kedokteran \\ Universitas Muhammadiyah Sumatera Utara Medan \\ Email: dr.robitahasfur@yahoo.com
}

\begin{abstract}
Squid ink consists of DHI, DHICA, and 2-carboxyl indole that improve lipid profile and remove foam cells in blood vessel walls. This study was aimed to analyze the effect of squid ink on atherosclerosis-induced Wistar rats. This was an experimental study. We used randomized controlled trial with pre-post test design for lipid profile assessment and randomized post-test only control design for blood vessel evaluation (foam cells in layers of coronary artery). Samples were 27 Wistar rats, divided into three groups; all were atherosclerosis-induced with initial injection of $0.006 \mathrm{mg}$ iv adrenalin on day 1 , followed by standard diet and egg yolk until day 30. Squid ink extract was given to group P1 and P2 on days 15-30 in different doses, but not to control group. Data were analyzed by using Saphiro-Wilk test and paired t-test. The results showed that P2 group had decreased means of total cholesterol $(-33.62 \mathrm{mg} / \mathrm{dl})$, triglyceride $(-28.00 \mathrm{mg} / \mathrm{dl})$, and LDL cholesterol $(-28.16 \mathrm{mg} / \mathrm{dl})$, but an increased mean of HDL cholesterol $(11.60 \mathrm{mg} / \mathrm{dl})$. There were decreased numbers of foam cells in the layers of coronary arteries of P1 and P2 group compared to the control group. Conclusion: Squid ink extract could lower total cholesterol, triglyceride, and LDL cholesterol levels, and increase HDL cholesterol level. Moreover, it could remove foam cells from the layers of coronary arteries.
\end{abstract}

Keywords: squid ink, atherosclerosis, lipid profile, foam cells

Asbtrak: Tinta cumi memiliki kandungan DHI, DHICA, dan 2-carboxyl indole yang dapat memperbaiki profil lipid dan mengurangi sel busa pembuluh darah. Penelitian ini bertujuan untuk mengetahui pengaruh pemberian ekstrak tinta cumi terhadap tikus yang diinduksi aterosklerosis. Jenis penelitian ialah eksperimental dengan randomized controlled with pre-post test design untuk penilaian profil lipid dan post test only design untuk penilaian pembuluh darah (sel busa dalam dinding arteri koronaria). Sampel terdiri dari 27 tikus Wistar jantan, dibagi secara random menjadi tiga kelompok; kesemuanya diberi induksi aterosklerosis dengan injeksi inisial adrenalin 0,006 mg iv pada hari ke-1, dilanjutkan diet standar dan diet kuning telur sampai hari ke-30. Tikus kelompok kontrol tidak diberikan ekstrak tinta cumi; tikus kelompok perlakuan 1 dan perlakuan 2 diberikan tambahan ekstrak tinta cumi pada hari ke 16 sampai hari ke 30 dengan dosis yang berbeda. Analisis data dengan uji Saphiro-Wilk dan uji paired t-test. Hasil penelitian memperlihatkan penurunan rerata setelah perlakuan pada kelompok P2 ialah kolesterol total $(-33,62 \mathrm{mg} / \mathrm{dl})$, trigliserida $(-28,00 \mathrm{mg} / \mathrm{dl})$, dan kolesterol LDL $(-28,16 \mathrm{mg} / \mathrm{dl})$, serta peningkatan rerata kolesterol HDL (11,60 mg/dl). Terdapat penurunan jumlah sel busa kelompok perlakuan P1 dan P2 dibandingkan kelompok kontrol. Simpulan: Pemberian ekstrak tinta cumi menurunkan kadar kolesterol total, trigliserida dan kolesterol LDL, meningkatkan kadar kolesterol HDL, serta menurunkan jumlah sel busa dalam dinding arteri koronaria.

Kata kunci: tinta cumi, aterosklerosis, profil lipid, sel busa 
Tinta cumi (squid ink) adalah hasil sekresi yang dihasilkan dan dikeluarkan oleh kantung tinta. ${ }^{1}$ Kantung tinta telah menjadi produk yang tidak memiliki nilai jual dan dapat menyebabkan pencemaran lingkungan tanpa adanya pengolahan yang tepat. Tinta cumi telah digunakan sebagai pengobatan tradisional Cina yang digunakan pertama kali untuk pengobatan nyeri dada. Ilmu kesehatan modern juga telah dapat membuktikan tinta cumi sebagai alternatif pengobatan yang digunakan dalam pengobatan terapetik, ${ }^{2}$ namun penelitian di Indonesia tentang efek tinta cumi ini belum banyak dilakukan.

Kandungan lengkap dalam tinta cumi masih terus diteliti. Beberapa penelitian mengatakan bahwa kandungan utama tinta cumi ialah melanin. ${ }^{3}$ Kandungan tinta seperti eumelanin terdiri dari 5,6dihydroxyindole (DHI) dan 5,6-dihydroxyindole-2-carboxylic acid (DHICA) serta kandungan 2-carboxyl indole pada melanin yang dapat mengikat $\mathrm{Fe}^{2+}$ untuk menperlambat proses oksidasi yang berpengaruh terhadap lipid darah. ${ }^{4}$

Efek tinta cumi tersebut sangat berpengaruh pada patogenesis aterosklerosis yaitu suatu perubahan pada dinding arteri yang diakibatkan oleh multifaktor serta memiliki manifestasi penebalan dan kekakuan pada pembuluh arteri. Faktor risiko aterosklerosis yang terpenting ialah konsentrasi kolesterol yang tinggi dalam plasma darah yaitu dalam bentuk lipoprotein dengan densitas rendah, low density lipoprotein (LDL). ${ }^{5}$ Faktor risiko lain yang juga sangat berperan ialah adanya peningkatan radikal bebas yang berperan penting dalam pembentukan plak atheromatosa. Kolesterol LDL yang teroksidasi oleh radikal bebas akan lebih mudah menempel pada dinding dalam arteri yang selanjutnya akan menjadi plak. Radikal bebas juga dapat membentuk aterosklerosis melalui mekanisme perusakan dinding pembuluh darah, dan memudahkan terbentuknya plak. ${ }^{6}$

Plak ateromatosa merupakan salah satu tahapan perjalanan penyakit aterosklerosis. Tahapan perjalanan aterosklerosis secara histopatologik yaitu sebagai berikut: tahap lesi awal (fatty streak) dimulai dengan terjadinya kerusakan sel endotel karena stres regangan (shear stress). Perkembangan fatty streak menjadi lesi fibrotik dipengaruhi oksidasi dari kolesterol LDL. Tahap kedua yaitu lesi lanjut (plak ateroma-aterosklerotik) ditandai dengan adanya tutup fibrotik (fibrotic cap) sehingga dapat menyebabkan sumbatan parsial dari arteri, dan tahap yang terakhir ialah lesi komplikata. Dengan demikian cara pencegahan aterosklerosis berdasarkan perjalanan penyakitnya ialah dengan mengurangi kolesterol dan radikal bebas. ${ }^{6}$

Dewasa ini aterosklerosis merupakan masalah kesehatan paling besar, terutama untuk negara yang sudah maju dan negara berkembang. Dampak dari aterosklerosis juga menjadi masalah karena penyakit ini merupakan penyakit awal pencetus dari berbagai penyakit mematikan lainnya. Penelitian ini bertujuan untuk menganalisis pengaruh pemberian tinta cumi terhadap aterosklerosis sehingga kedepannya tinta cumi dapat dimanfaatkan sebagai alternatif pencegahan aterosklerosis.

\section{METODE PENELITIAN}

Jenis penelitian ini ialah true experimental dengan randomized controlled pre-post test design untuk penilaian profil lipid serta post test only control group design untuk menilai sel busa dalam dinding arteri koronaria pada tikus Wistar.

Penelitian dilakukan di Laboratorium Terpadu Fakultas Kedokteran Universitas Muhammadiyah Sumatera Utara dalam waktu 30 hari. Subyek penelitian ialah tikus putih Wistar (Rattus norvegicus strain Wistar) dengan jenis kelamin jantan, umur 2-3 bulan, berat badan 20-30 gr, dan dalam kondisi sehat. Variabel bebas dalam penelitian ini ialah pemberian ekstrak tinta cumi sedangkan variabel tergantung ialah profil lipid (kolesterol total, trigliserida, kolesterol LDL, kolesterol HDL) dan sel busa pada pembuluh darah jantung tikus. Besar sampel mengacu pada rumus Federer. 
Penelitian ini menggunakan sembilan ekor tikus untuk setiap kelompok. Jumlah tikus yang digunakan dalam penelitian sebanyak 27 ekor yang dibagi secara random menjadi tiga kelompok penelitian yaitu kelompok K (kontrol) tanpa pemberian ekstrak tinta cumi, hanya diberikan induksi aterosklerosis; kelompok P1 diberikan induksi aterosklerosis dan ekstrak tinta cumi $1,2 \mathrm{gr} / \mathrm{kg} \mathrm{BB}$; dan kelompok P2 diberikan induksi aterosklerosis dan ekstrak tinta cumi $2,4 \mathrm{gr} / \mathrm{kg}$ BB. Aklimatisasi dilakukan di awal penelitian selama tujuh hari dengan tujuan untuk menyesuaikan kondisi hewan coba pada keadaan stres yang sama dan penyesuaian terhadap lingkungan.

Data pre test profil lipid darah tikus diperiksa setelah 15 hari pemberian induksi aterosklerosis sedangkan data post test diambil setelah 15 hari pemberian ekstrak tinta cumi. Induksi arterosklerosis dilakukan pada hewan coba dengan cara diberi injeksi inisial adrenalin 0,006 mg i.v. pada hari pertama, dilanjutkan dengan diet intermiten kuning telur 10 mg tiap dua hari sekali serta diet standar setiap hari selama 30 hari. $^{5}$

Ekstraksi dibuat dengan mengambil kantong tinta sotong (Sepia officinalis) lalu memasukkan tintanya ke dalam wadah. Tinta tersebut dimasukkan ke dalam erlenmeyer berbeda kemudian diaduk dengan menggunakan shaker dengan kecepatan $250 \mathrm{rpm}$ (rotation per minutes) selama 1 jam kemudian didiamkan selama 24 jam. Ekstraksi dilakukan pada gelas beker yang bagian luarnya telah dilapisi aluminium foil. Larutan ekstrak tinta sotong (Sepia officinalis) disaring. Ekstrak yang diperoleh dipindahkan ke dalam botol gelap agar terhindar dari sinar matahari.

Data dianalisis menggunakan program komputer dan diuji statistik setelah sebelumnya dilakukan uji normalitas menggunakan uji Shapiro-Wilk dan untuk melihat perbedaan kadar kolesterol total, trigliserida, kolesterol HDL, sebelum dan sesudah perlakuan pada masing masing kelompok dilakukan uji paired t-test.
HASIL PENELITIAN DAN BAHASAN Pengaruh pemberian ekstrak tinta cumi terhadap profil lipid tikus Wistar yang diberi induksi aterosklerosis.

Tabel 1 memperlihatkan hasil pemeriksaan profil lipid pada kelompok kontrol (K) dan kelompok perlakuan (P1 dan P2) sebelum dan setelah pemberian perlakuan ekstrak tinta cumi. Terjadi penurunan kadar kolesterol total pada kelompok P2 sebesar 33,62 $\mathrm{mg} / \mathrm{dl}$ setelah pemberian perlakuan ekstrak tinta cumi 2,4 gr/kg BB. Hasil uji statistik menyatakan bahwa terdapat perbedaan bermakna kadar kolesterol total antara sebelum dan setelah perlakuan $(P$ $<0,05)$. Rerata kadar trigliserida pada kelompok P2 sebelum perlakuan lebih tinggi yaitu $61,40 \mathrm{mg} / \mathrm{dl}$ dibanding rerata setelah perlakuan yaitu 33,40 mg/dl. Hasil uji beda paired t-test menyatakan bahwa terdapat perbedaan rerata kadar trigliserida darah antara sebelum dan setelah perlakuan $(P<0,05)$. Rerata kadar kolesterol LDL menunjukkan bahwa pada kelompok P2 terjadi penurunan kadar kolesterol LDL setelah perlakuan. Hasil uji statistik menyatakan terjadi penurunan secara bermakna $(P<0,05)$ dari rerata kolesterol LDL setelah perlakuan. Rerata kadar kolesterol HDL sebelum setelah perlakuan pada kelompok P2 ialah 22,00 mg/dl dan setelah setelah perlakuan ialah $33,60 \mathrm{mg} / \mathrm{dl}$. Rerata kolesterol HDL setelah perlakuan lebih tinggi dibandingkan sebelum perlakuan. Hasil uji statistik menyatakan bahwa terdapat perbedaan rerata kadar kolesterol HDL antara sebelum dan setelah perlakuan pada kelompok P2 $(P<0,05)$.

Penyebab terjadinya aterosklerosis ialah multifaktorial. Faktor terpenting ialah profil lipid terutama konsentrasi kolesterol yang tinggi dalam plasma darah dalam bentuk lipoprotein densitas rendah atau LDL (low density lipoprotein). ${ }^{7,8}$ Selain profil lipid, radikal-radikal bebas memainkan peranan penting dalam pembentukan plak ateromatosa yang merupakan awal dari aterosklerosis. Bila LDL teroksidasi oleh radikal bebas, LDL akan lebih mudah menempel pada dinding bagian dalam 
arteri, dan selanjutnya terbentuk plak. Perjalanan penyakit aterosklerosis ini ditambah dengan efek radikal bebas yang memiliki mekanisme merusak dinding pembuluh darah. ${ }^{8,9}$

Penelitian sebelumnya membuktikan bahwa tikus Wistar jantan yang diinjeksi adrenalin dan dilanjutkan dengan pemberian diet kuning telur intermiten dapat mengalami proses aterosklerosis. Penelitian tersebut juga membuktikan adanya hubungan antara tingginya kadar kolesterol darah dengan terbentuknya aterosklerosis yang dapat dinilai dari pemeriksaan histopatologik pembuluh darah tikus. ${ }^{10}$
Rerata kadar kolesterol total, trigliserida, kolesterol LDL lebih rendah dan kadar kolesterol HDL lebih tinggi pada kelompok P2 dibandingkan dengan kelompok P1 yang diberi dosis ekstrak tinta cumi lebih rendah dan kelompok $\mathrm{K}$ yang tidak diberi ekstrak tinta cumi. Hasil ini menyatakan bahwa pemberian ekstrak tinta cumi menyebabkan penurunan kadar kolesterol total, trigliserida, kolesterol LDL dan peningkatan kadar kolesterol HDL setelah pemberian ekstrak tinta cumi 2,4 $\mathrm{g} / \mathrm{kg} \mathrm{BB}$ dan $1,2 \mathrm{~g} / \mathrm{kg}$ BB selama 15 hari dengan efek terbaik pada dosis yang lebih tinggi yaitu kelompok P2.

Tabel 1. Hasil pemeriksaan sampel darah tikus

\begin{tabular}{cccccc}
\hline Parameter & Kelompok & $\begin{array}{c}\text { Pre test } \\
\text { Mean } \pm \text { SD }\end{array}$ & $\begin{array}{c}\text { Post test } \\
\text { Mean } \pm \text { SD }\end{array}$ & $\begin{array}{c}\Delta \\
\text { Perubahan }\end{array}$ & P \\
\hline Kolesterol & K & $37,0 \pm 9,0$ & $56,0 \pm 5,4$ & $-19,60$ & $0,00^{\text {a }}$ \\
total & P1 & $60,5 \pm 13$ & $45,40 \pm 7,2$ & 15,10 & $0,00^{\text {a }}$ \\
& P2 & $71,6 \pm 6,4$ & $37,90 \pm 8,7$ & 33,62 & $0,00^{\text {a }}$ \\
\hline Trigliserida & K & $36,40 \pm 8,6$ & $62,60 \pm 19,1$ & $-26,20$ & $0,05^{\text {a }}$ \\
& P1 & $53,30 \pm 3,5$ & $42,80 \pm 3,9$ & 10,50 & $0,00^{\text {a }}$ \\
& P2 & $61,40 \pm 18,5$ & $33,40 \pm 11,5$ & 28,00 & $0,00^{\text {a }}$ \\
\hline LDL & K & $20,92 \pm 9,4$ & $25,96 \pm 10,2$ & $-5,04$ & $0,298^{\text {a }}$ \\
& P1 & $23,80 \pm 8,2$ & $13,74 \pm 7,9$ & 10,06 & $0,003^{\text {a }}$ \\
& P2 & $37,90 \pm 11,0$ & $9,74 \pm 6,7$ & 28,16 & $0,000^{\text {a }}$ \\
\hline HDL & K & $29,50 \pm 10,9$ & $16,60 \pm 3,2$ & 12,90 & $0,06^{\text {a }}$ \\
& P1 & $18,70 \pm 4,3$ & $23,50 \pm 4,0$ & $-4,80$ & $0,00^{\text {a }}$ \\
& P2 & $22,00 \pm 5,1$ & $33,60 \pm 7,7$ & $-11,60$ & $0,00^{\text {a }}$ \\
\hline
\end{tabular}

$\mathrm{a}=$ uji paired $t$-test

\section{Hasil pemeriksaan histopatologik pembuluh darah.}

Sel busa yang terdapat pada dinding pembuluh darah aorta tikus menunjukkan adanya penimbunan LDL pada pembuluh darah. Kolesterol LDL yang berikatan dengan radikal bebas akan membentuk LDL teroksidasi (LDL-oks) yang bersifat kemoatraktan terhadap monosit sehingga terjadi fagositosis dan mengakibatkan peningkatan jumlah sel busa. LDL-oks ini juga dapat menyebabkan terjadinya disfungsi endotel, sehingga terjadi gangguan permeabilitas dan migrasi lekosit ke dalam dinding arteri. Selain itu, LDLoks mampu memicu mitosis dari miosit arteri. Beberapa keadaan tersebut akhirnya akan menyebabkan terjadinya penambahan ketebalan dinding arteri, terutama pada dinding aorta abdominalis. ${ }^{11,12}$

Pada penelitian ini, banyaknya sel busa berbeda setiap kelompoknya. Pada kelompok P2 tidak terdapat sel busa sedangkan pada P1 dengan dosis ekstrak tinta cumi yang lebih rendah masih terdapat sel busa tetapi lebih sedikit dibandingkan dengan kelompok $\mathrm{K}$ yang tidak diberi ekstrak tinta cumi (Gambar 1-3). 


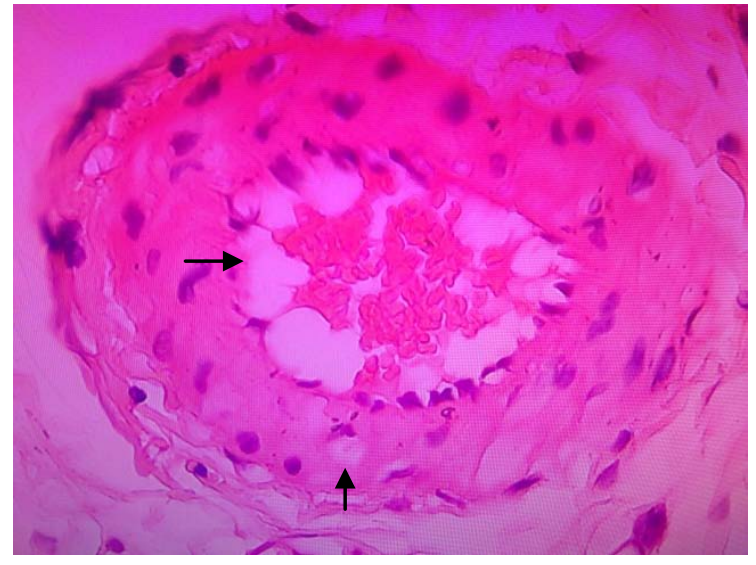

Gambar 1. Kelompok kontrol: arteri koronaria (pembesaran 400x). Anak panah menunjukkan sel busa (foam cell) dalam tunika intima dan media

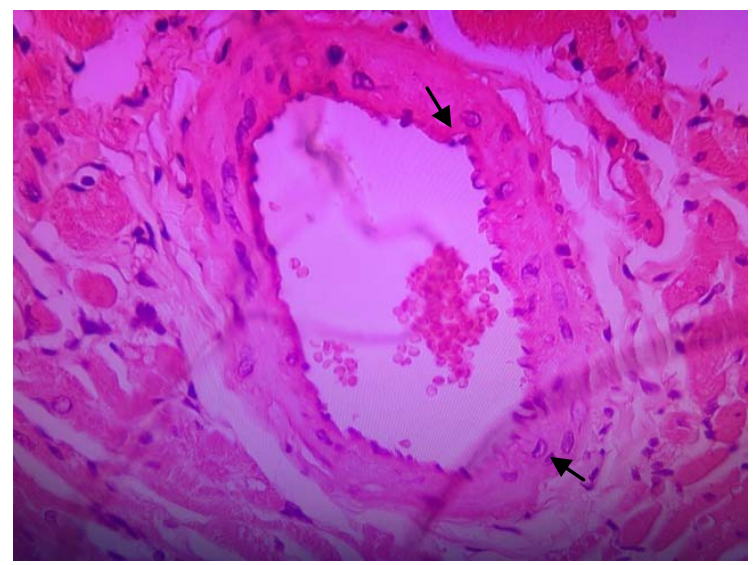

Gambar 2. Kelompok P1: arteri koronaria (pembesaran 400x), masih terdapat sel busa (anak panah) tetapi jumlahnya telah berkurang dibandingkan kelompok kontrol

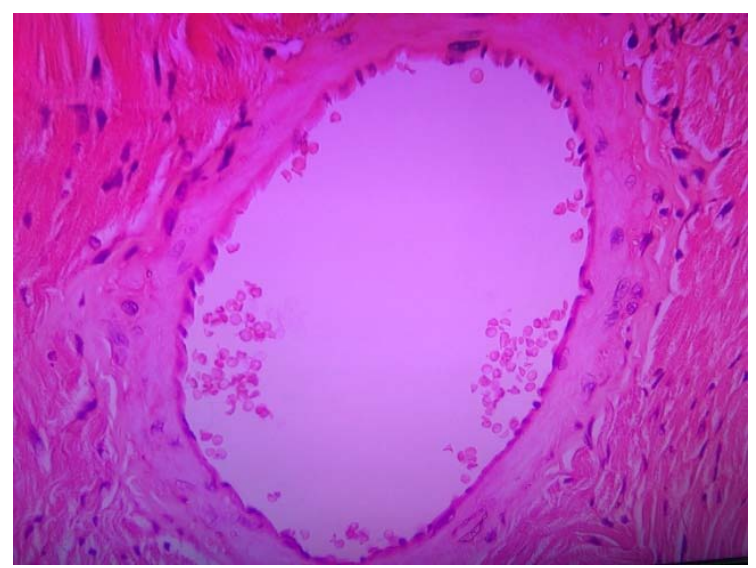

Gambar 3. Kelompok P2: arteri koronaria (pembesaran 400x), tidak terlihat sel busa

Hasil penelitian ini sesuai dengan penelitan sebelumnya yang menerangkan bahwa kandungan ekstrak melanin pada tinta cumi memiliki kemampuan mengikat $\mathrm{Fe}^{2+}$ yang merupakan ion logam yang paling efektif mempercepat proses oksidasi dari lipid. Melanin dapat mengikat $\mathrm{Fe}^{2+}$ dikarenakan terdapat struktur 2-carboxyl indole yang dapat berikatan kuat dengan $\mathrm{Fe}^{2+}$.

Tinta cumi juga memiliki kandungan DHI dan DHICA yang mempunyai karakter kuat untuk menyerap struktur -OH dan - $\mathrm{NH}$ yang membuktikan bahwa kandungan ini memiliki kemampuan antioksidan dengan Inhibitory Concentration (IC50) dalam pembersihan $\mathrm{O}_{2}^{-}$(superoksid) lebih efisien dibandingkan dengan obat antioksidan komersil (Carnosin) dan dalam pembersihan -OH kedua zat ini memiliki nilai yang sama. ${ }^{14}$ Dengan adanya antioksidan, mekanisme modifikasi oksidatif kolesterol LDL menjadi LDL-oks itu tidak akan terjadi karena antioksidan akan mengikat radikal bebas, sehingga semua akibat lanjut dari modifikasi oksidatif kolesterol LDL dapat dicegah. ${ }^{15}$

Didukung juga oleh penelitian lain yang menguji tinta cumi menggunakan uji DPPH dan uji aktivitas anti lipid peroksidase, ternyata pada kedua uji ini dibuktikan tinta cumi merupakan antioksidan alami yang baik. ${ }^{16}$ Efek lainnya dari melanin tinta cumi ialah efek positif pada profil lipid darah. Tinta cumi dapat menurunkan kadar kolesterol total, trigliserida, kolesterol LDL, dan meningkatkan kadar kolesterol HDL dalam serum. ${ }^{4}$

\section{SIMPULAN}

Pemberian ekstrak tinta cumi per oral dengan dosis 2,4 g/kg BB setiap harinya selama 15 hari pada tikus Wistar dengan induksi aterosklerosis dapat memperbaiki profil lipid yaitu menurunkan kadar kolesterol total, trigliserida, dan kadar kolesterol LDL, serta meningkatkan kadar kolesterol HDL. Secara mikroskopik, perlakuan ini dapat menurunkan jumlah sel busa dalam dinding arteri koronaria secara bermakna yang menunjukkan bahwa 
pemberian tinta cumi berpengaruh terhadap lesi aterosklerosis pada tikus Wistar.

Ucapan terima kasih ditujukan kepada Dirjen Dikti yang melalui Program Kreativitas Mahasiswa telah mendanai penelitian ini dan juga kepada Akademia Universitas Muhammadiyah Sumatera Utara yang telah membantu penyelesaian penelitian ini.

\section{DAFTAR PUSTAKA}

1. Madaras F, Gerber JP, Peddie F, Kokkinn MJ. The effect of sampling methods on the apparent constituents of ink from the squid Sepioteuthis australis. J Chem Ecol. 2010;36:1171-9

2. Werdhasari A. Peran antioksidan bagi kesehatan. Jurnal Biotek Medisiana Indonesia. 2014;3(2):59-68.

3. Derby CD. Cephalopod ink: Production, chemistry, functions and applications. Mar Drugs. 2014;12:2700-30.

4. Lei M, Wang JF, Pang L, Wang YM, Chen SG, Xue CH. Effects of sepia on the metabolization of blood lipid and antioxidation ability in hyperlipidemia rats. J Mar Drugs. 2007;3:30-3.

5. Nugroho A. Pengaruh pemberian suplemen melatonin terhadap jumlah sel busa dan ketebalan dinding aorta abdominalis tikus Wistar yang diinduksi aterosklerosis [Karya Tulis Ilmiah]. Semarang: Fakultas Kedokteran Universitas Diponegoro; 2005.

6. Rahman A. Faktor-faktor risiko mayor aterosklerosis pada berbagai penyakit aterosklerosis di RSUP dr. Kariadi Semarang [Karya Tulis Ilmiah]. Semarang: Fakultas Kedokteran Universitas Diponegoro; 2012.

7. Guyton AC, Hall JE. Buku Ajar Fisiologi Kedokteran. Jakarta: EGC, 1997.

8. Luna LG. Manual of Histologic Staining Methods of the Armed Forces Institute of Pathology (3rd ed). New York: McGraw-Hill, 1968.

9. Bock SJ, Boyette M. Awet Muda bersama Melatonin. Solo: Dabara Publisher, 1995.

10. Kustiyah I, Prasetyo A, Sarjadi. Pengaruh berbagai variasi dosis ekstrak Morinda citrifolia terhadap kadar lipid serum dan perkembangan lesi aterosklerotik pada aorta abdominalis tikus wistar. Media Medika Indonesia. 2003;38(4): 193-202.

11. Collins T, Cybulski MI. NF-kappaB: Pivotal mediator or innocent bystander in atherogenesis. $\mathrm{J}$ Clin Invest. 2001;107(3):255-64.

12. Griendling KK, Harrison DG. Out, damned dot: Studies of the NAD(P)H oxidase in atherosclerosis. J Clin Invest. 2001;108(10):1423-4.

13. Lin LC, Chen WT. The study of antioxidant effects in melanins extracted from various tissues of animals. Asian-Aust J Anim Sci. 2004;18:277-81.

14. Xin G, Shiguo $C$, Changhu $X$, Yaqin $H$, Donghong L, Xingqian $Y$. Ultrasound-assisted degradation for preparing soluble melanin from squid ink and its anti-oxidant activity. Journal of Fisheries of China. 201307.

15. Lisa CW, Nica MB, Murray WH. Antiatherogenic properties of naringenin, a citrus flavonoid. Cardiogenic Drugs Reviews. 1999;17(2). [cited 2017 Jun 25]. Availabe from: http://www.nevapress.com/cdr/full/17/ 2/160.pdf $>$.

16. Fahmy SR, Soliman AM. In vitro antioxidant, analgesic and cytotoxic activities of Sepia officinalis ink and Coelatura aegyptiaca extracts. Afr J Phar Pharmacol. 2013;7(22):1512-22. 